\title{
Radiocarbon
}

An International Journal of Cosmogenic Isotope Research

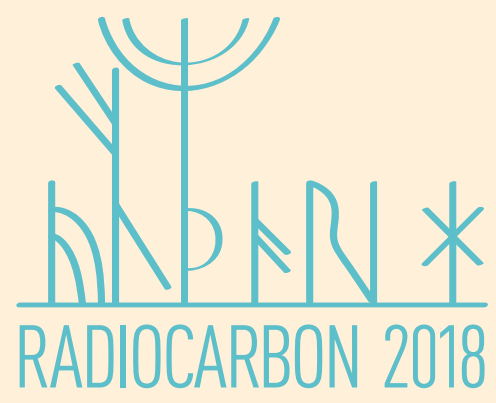

Radiocarbon 2018 Conference Proceedings Trondheim, Norway, June 17-22, 2018

\section{Part 2 of 2}

Guest Editor Marie-Josée Nadeau
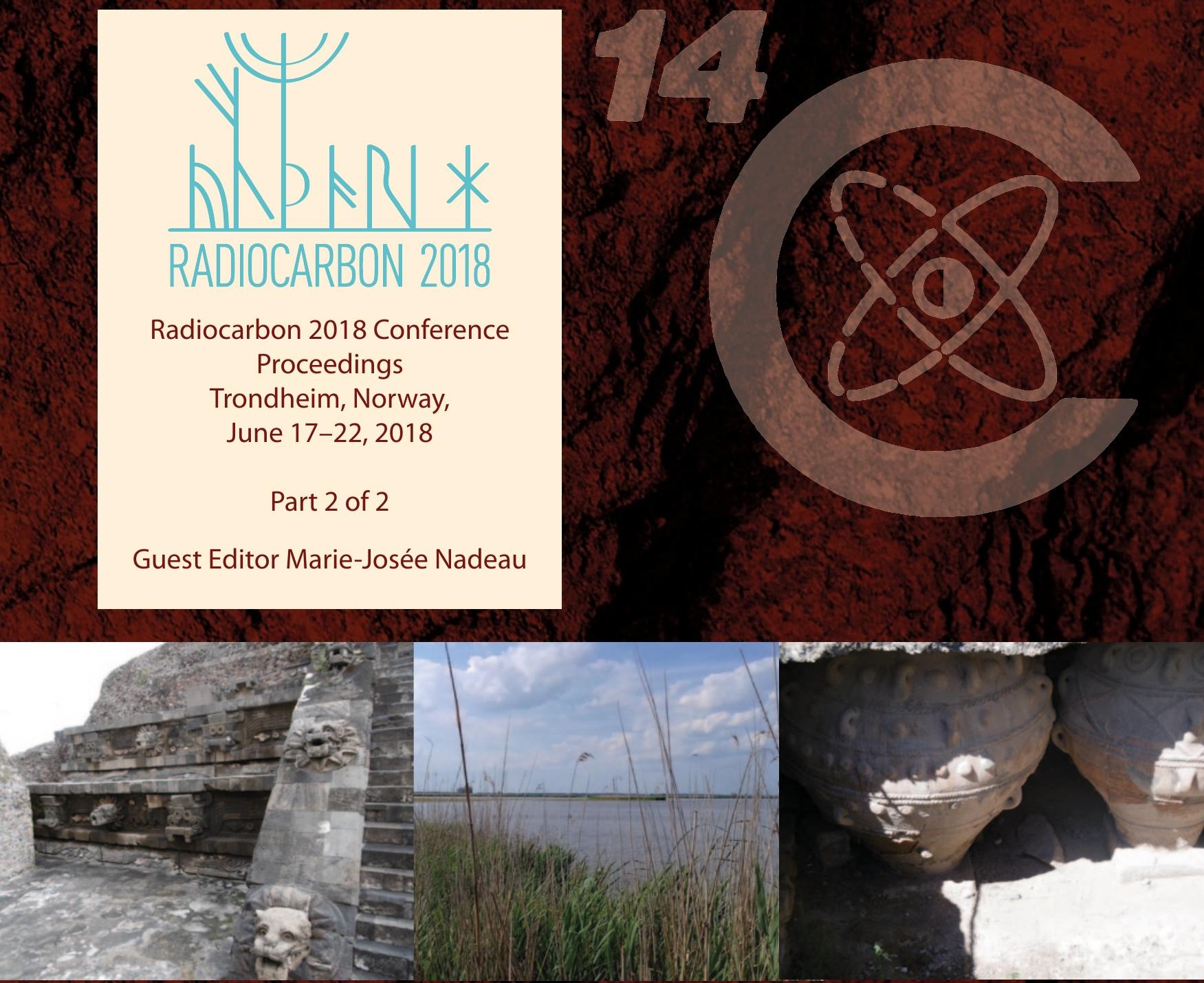


\title{
Radiocarbon
}

An International Journal of Cosmogenic Isotope Research

\section{EDITOR}

A. J. T. Jull · University of Arizona

\section{MANAGING EDITOR}

Kimberley Tanner Elliott · University of Arizona

\section{ASSOCIATE EDITORS}

Edouard Bard · Collège de France

Nancy Beavan · Cardiff University

Warren Beck · University of Arizona

Elisabetta Boaretto · Weizmann Institute

Christopher Bronk Ramsey · Oxford University

George S. Burr · University of Arizona

Owen K. Davis · University of Arizona

Ellen R. M. Druffel · University of California-Irvine

Pieter Grootes · Christian-Albrechts University

Irka Hajdas $\cdot$ ETH Zurich

Derek Hamilton · University of Glasgow

Christine Hatté $\cdot$ Laboratoire des Sciences du Climat et

l'Environnement

Gregory Hodgins · University of Arizona

Quan Hua - Australian Nuclear Science and Technology

Organisation

Yaroslav Kuzmin · Russian Academy of Sciences
Steven W. Leavitt · University of Arizona

Ann P. McNichol · Woods Hole Oceanographic Institution

Mihály Molnár · Hertelendi Laboratory of Environmental

Studies, Hungary

Toshio Nakamura $\cdot$ Nagoya University

Jesper Olsen · Aarhus AMS Center

Charlotte Pearson · University of Arizona

Pavel Povinec $\cdot$ Comenius University

Paula J. Reimer · Queen's University Belfast

E. Marian Scott · University of Glasgow

John R. Southon · University of California-Irvine

Jocelyn Turnbull · GNS Science

Johannes van der Plicht · Groningen University

Antoine Zazzo · Muséum national d'Histoire naturelle

Weijian Zhou · Institute of Earth Environment, Chinese

Academy of Science

Radiocarbon (ISSN 0033-8222) is published quarterly by Cambridge University Press, One Liberty Plaza 20th Floor New York, NY 10006. (C) 2019 by the Arizona Board of Regents on behalf of the University of Arizona. All rights reserved.

\section{Editorial Office}

Communications should be addressed to the Managing Editor, Radiocarbon, Department of Geosciences, The University of Arizona, 4717 East Fort Lowell Road, Tucson, AZ 85712-1201 USA. Tel.: +1 (520) 621-0641; Fax: +1 (520) 621-0584; Email: kimelliott@email.arizona.edu. Contributors should consult the Instructions for Contributors, which is available on the journal's Web site: cambridge.org/rdc.

\section{Subscriptions}

Annual subscription rates for Volume 61, 2019: Institutional rate is (print and electronic) $\$ 524$ in the USA, Canada, and Mexico, £338 + VAT elsewhere. Institutional rate (electronic only) \$381 in the USA, Canada, and Mexico, £245 + VAT elsewhere. Individual rate is (print and electronic) $\$ 172$ in the USA, Canada, and Mexico, $£ 111+$ VAT elsewhere. Individual rate (electronic only) \$132 in the USA, Canada, and Mexico, £86 + VAT elsewhere. Please direct subscription inquiries and requests for back issues to Customer Services at Cambridge University Press, email: subscriptions_newyork@cambridge.org (USA, Canada, and Mexico) or journals@cambridge.org (outside of USA, Canada, and Mexico).

\section{Advertising}

To advertise in the journal email advertising@cambridge.org or telephone +1 (212) 3375062 in the USA, Canada, or Mexico; email ad sales@cambridge.org or telephone+44(01223) 325898 in the rest of the world.

\begin{abstract}
ing and indexing
Radiocarbon is indexed and/or abstracted by the following sources: Anthropological Index; Anthropological Literature; Art and Archaeology Technical Abstracts; Bibliography and Index of Geology (GeoRef); British Archaeological Bibliography; Chemical Abstracts; Chemistry Citation Index; Current Advances in Ecological and Environmental Sciences; Current Contents (ISI); FRANCIS (Institut de l'Information Scientifique et Technique - CNRS); Geographical Abstracts; Geological Abstracts; Oceanographic Literature Review; Science Citation Index; Social Sciences Citation Index.
\end{abstract}

\section{List of laboratories}

Our comprehensive list of laboratories is published annually, and is also available at www.radiocarbon.org. We ask all laboratory directors to provide their laboratory code designation, as well as current telephone and fax numbers, and email addresses. Changes in names or addresses, additions or deletions should be reported to the managing editor. Conventional and AMS laboratories are arranged in alphabetical order by country, and we include laboratories listed by code designation.

\section{Permissions}

No part of this publication may be reproduced, in any form or by any means, electronic, photocopying or otherwise, without permission in writing from Cambridge University Press. Policies, request forms and contacts are available at: http://journals. cambridge.org/action/rightsAndPermissions. Permission to copy (for users in the USA) is available from Copyright Clearance Center: http://www.copyright.com, email: info@copyright.com.

Postmaster: Send address changes to Radiocarbon, Cambridge University Press, One Liberty Plaza, New York, NY 10006, USA. 


\section{Proceedings of the 23rd International \\ Radiocarbon Conference \\ Radiocarbon}

Vol 61, Nr 6, 2019

Part 2 of 2

\section{CONTENTS}

\section{INTRODUCTION}

\section{ANTHROPOGENIC IMPACTS}

Radiocarbon Level in the Atmosphere of Ramnicu Valcea, Romania

I Faurescu, C Varlam, I Vagner, D Faurescu, D Bogdan, D Costinel

Pre- and Post-Accident ${ }^{14} \mathrm{C}$ Activities in Tree Rings Near the Fukushima Dai-Ichi Nuclear

Power Plant

Tetsuya Matsunaka, Kimikazu Sasa, Tsutomu Takahashi, Masumi Matsumura,

Yukihiko Satou, Hongtao Shen, Keisuke Sueki, Hiroyuki Matsuzaki.

Radiocarbon Characterization Study of Atmospheric PM2.5 in Beijing During the 2014

APEC Summit

Yijun Pang, Bo Yu, Ming He, Shan Jiang, Qingzhang Zhao, Hongtao Shen, Shaoyong Wu,

Xuran Yang, Fangfang Wang, Qi Meng, Yuxuan Zhang....

\section{ARCHAEOLOGY}

Update on the Absolute Chronology of the Migration Period in Central Europe (375-568 AD):

New Data from Maria Ponsee, Lower Austria

Jakub Kaizer, Eva Maria Wild, Peter Stadler, Maria Teschler-Nicola, Peter Steier

Radiocarbon Dating of Textile Components from Historical Silk Costumes and Other Cloth

Products in the Ryukyu Islands, Japan

Toshio Nakamura, Takako Terada, Chikako Ueki, Masayo Minami

The Chronology of Medieval Copenhagen

Jesper Olsen, Hanna Dahlström, Bjørn Poulsen.

Dissolved Inorganic Radiocarbon Content of the Western Coral Sea: Implications for

Intermediate and Deep Water Circulation

Aymeric PM Servettaz, Yusuke Yokoyama, Shoko Hirabayashi, Markus Kienast,

Yosuke Miyairi, Mahyar Mohtadi

Multiple Radiocarbon Dating of Human Remains: Clarifying the Chronology and Sequences

of Burials in the Late Neolithic Dolmen of Oberbipp (Switzerland)

Noah Steuri, Inga Siebke, Anja Furtwängler, Sönke Szidat, Johannes Krause,

Sandra Lösch, Albert Hafner. 
New Radiocarbon-Based Assessment Supports the Prominence of Tel Lachish During Late Bronze Age IB-IIA

Lyndelle Webster, Katharina Streit, Michael Dee, Irka Hajdas, Felix Höflmayer.

\section{CALIBRATION \& CALIBRATION METHODS}

The Best Possible Time Resolution: How Precise Could a Radiocarbon Dating Method Be? I Svetlik, A J T Jull, M Molnár, P P Povinec, T Kolár, P Demján, K Pachnerova Brabcova V Brychova, D Dreslerová, $M$ Rybniček, P Simek.

\section{DENDROCHRONOLOGY \& SINGLE-YEAR ANALYSIS}

Radiocarbon Dating of Chinese Ancient Tea Trees Jia Chen, Hongtao Shen, Kimikazu Sasa, Haihui Lan, Tetsuya Matsunaka, Masumi Matsumura, Tsutomu Takahashi, Seiji Hosoya, Ming He, Yun He, Zhaomei Li, Zhenchi Zhao, Mingji Liu, Siyu Wei, Mingli Qi, Qingzhang Zhao, Xiuju Qin, Xinqiang Chen, Shan Jiang

A Study of Variation of the 11-Yr Solar Cycle before the Onset of the Spoerer Minimum Based on Annually Measured ${ }^{14} \mathrm{C}$ Content in Tree Rings

Toru Moriya, Hiroko Miyahara, Motonari Ohyama, Masataka Hakozaki, Mirei Takeyama, Hirohisa Sakurai, Fuyuki Tokanai

Radiocarbon Pretreatment Comparisons of Bald Cypress (Taxodium Distichum) Wood

Samples from a Massive Buried Deposit on the Georgia Coast, USA

Katharine G Napora, Alexander Cherkinsky, Robert J Speakman, Victor D Thompson, Robert Horan, Craig Jacobs.

The 1953-1965 Rise in Atmospheric Bomb ${ }^{14} \mathrm{C}$ in Central Norway

Helene Svarva, Pieter Grootes, Martin Seiler, Sølvi Stene, Terje Thun, Einar Voernes,

Marie-Josée Nadeau.

Radiocarbon Calibration around AD 1900 from Scots Pine (Pinus Sylvestris) Tree Rings

from Northern Norway

Helene Svarva, Pieter Grootes, Martin Seiler, Terje Thun, Einar Vaernes,

Marie-Josée Nadeau.

\section{DEVELOPMENTS IN MEASUREMENT TECHNIQUES}

Exploring Sample Size Limits of AMS Gas Ion Source ${ }^{14} \mathrm{C}$ Analysis at CologneAMS Jan Olaf Melchert, Alexander Stolz, Alfred Dewald, Merle Gierga, Philipp Wischhöfer,

Janet Rethemeyer.

A Low-Cost Continuous-Flow Gas Interface for Coupling an Elemental Analyzer with a

MICADAS AMS: Gas Flow Mathematical Model and First Results

Gary Salazar, Sönke Szidat.

Ion-Pair Ionization in $\mathrm{CO}_{2}$-Fed Cesium Sputter Sources

John S Vogel, Alexander M Stolz.

\section{DEVELOPMENTS IN SAMPLE PRETREATMENT}

Testing Sealed-Tube Graphitization at the NERC Radiocarbon Facility, East Kilbride Luz Maria Cisneros-Dozal, Xiaomei Xu, Sheng Xu.

Effect of Crystallinity of Apatite in Cremated Bone on Carbon Exchanges During Burial and

Reliability of Radiocarbon Dating

M Minami, H Mukumoto, S Wakaki, T Nakamura 
Reproducibility of $\mathrm{CO}_{2}$ Absorption Method for Measurement of Radiocarbon Using a Parr Bomb and LSC

Irina Vagner, Carmen Varlam, Denisa Faurescu, Diana Bogdan, Ionut Faurescu

Single Step Production of Graphite from Organic Samples for Radiocarbon Measurements

$K L$ Elder, $M L$ Roberts, $T$ Walther, $L X u$

Advances in the Radiocarbon Analysis of Carbon Dioxide at the NERC Radiocarbon Facility

(East Kilbride) Using Molecular Sieve Cartridges

M H Garnett, Josephine-Anne Newton, P L Ascough.

Novel Method of Extraction for Radiocarbon Measurements of Atmospheric Carbon Dioxide

K L Pugsley, T D J Knowles, S O'Doherty

A Suitable Procedure for Preparing of Water Samples Used in Radiocarbon Intercomparison H A Takahashi, M Minami, T Aramaki, H Handa, Y Saito-Kokubu, S Itoh, Y Kumamoto ....

\section{DIET STUDIES}

Approaches to Determine Reservoir Effects in Elk/Moose Bente Philippsen

\section{FORENSIC APPLICATIONS OF RADIOCARBON}

Bomb ${ }^{14} \mathrm{C}$ on Paper and Detection of the Forged Paintings of T'ang Haywen

Irka Hajdas, Philippe Koutouzis, Kate Tai, Laura Hendriks, Mantana Maurer,

Maria Belen Röttig.

\section{HYDROLOGY, LIMNOLOGY, OCEANOGRAPHY \& RESERVOIR EFFECTS}

An Investigation into ${ }^{14} \mathrm{C}$ Offsets in Modern Mollusk Shell and Flesh from Irish Coasts

Shows No Significant Differences in Areas of Carbonate Geology

$K$ R Allen, P J Reimer, D W Beilman, S E Crow.

Insight into Western Pacific Circulation from South China Sea Coral Skeletal Radiocarbon

Shoko Hirabayashi, Yusuke Yokoyama, Atsushi Suzuki, Yosuke Miyairi, Takahiro Aze,

Fernando Siringan, Yasuo Maeda,

Radiocarbon Age Offsets of Plants and Bioclasts in the Holocene Sediments from the

Miyazaki Plain, Southeast Coast of Kyushu, Southwest Japan

Toshimichi Nakanishi, Wan Hong, Mitsuhiro Kuwahata, Shinji Sugiyama,

Shoichi Shimoyama, Ken'ichi Ohkushi, Tatsuhiko Yamaguchi, Jung-Hun Park,

Gyujun Park, Futoshi Nanayama

Radiocarbon Age Offsets of Plants and Shells in Holocene Sediments from the Sukumo Plain,

Southwest Coast of Shikoku, Southwest Japan

Toshimichi Nakanishi, Tomohiro Tsuji, Futoshi Nanayama, Tatsuhiko Yamaguchi,

Yasuo Kondo, Michiharu Ikeda, Wan Hong......

\section{NEW AND UPDATED FACILITIES, STATUS REPORTS}

Status Report of the Trondheim Radiocarbon Laboratory

Martin Seiler, Pieter M Grootes, John Haarsaker, Sylvie Lélu, Izabela Rzadeczka-Juga,

Sølvi Stene, Helene Svarva, Terje Thun, Einar Varnes, Marie-Josée Nadeau

\section{OTHER RADIOCARBON APPLICATIONS}

Determination of Bio Content in Polymers Used in the Packaging of Food Products

C Telloli, A Rizzo, C Canducci, P Bartolomei 


\section{SOIL DYNAMICS}

New Radiocarbon Data from the Paleosols of the Nyírség Blown Sand Area, Hungary

Botond Buró, József Lóki, Erika Györi, Richárd Nagy, Mihály Molnár,

Gábor Négyesi

\section{STATISTICAL ANALYSIS \& MODELING}

CHRONOscope: Application for the Interactive Visualization of Carbon-14 and

Beryllium-10 Atmospheric Data

Andreas Neocleous, Margot Kuitems, Andrea Scifo, Michael Dee.

TERRESTRIAL ENVIRONMENT SEDIMENTOLOGY, PLANT, LANDSCAPE, ETC.

$\delta^{13} \mathrm{C}$ Values of Wood and Charcoal Reveal Broad Isotopic Ranges at the Base of the Food Web Bente Philippsen, Jesper Olsen, Søren A Sørensen, Bjørnar Måge.

Problems of Developing the Pleistocene Radiocarbon Chronology within High Mountain

Terranes by the Example of Russian Altai Anna Agatova, Roman Nepop, Elya Zazovskaya, Ivan Ovchinnikov, Piotr Moska

\section{ERRATUM}

Radiocarbon Pretreatment Comparisons of Bald Cypress (Taxodium Distichum) Wood

Samples from a Massive Buried Deposit on the Georgia Coast, USA - ERRATUM

Katharine G Napora, Alexander Cherkinsky, Robert J Speakman, Victor D Thompson,

Robert Horan, Craig Jacobs.

\section{CORRIGENDUM}

Approaches to Determine Reservoir Effects in Elk/Moose - CORRIGENDUM

Bente Philippsen 


\section{INTRODUCTION}

Dear readers,

We are pleased to present Part 2 of 2 of Radiocarbon 2018, the Proceedings of the 23rd International Radiocarbon Conference, which was held June 17-22, 2018, in Trondheim, Norway and hosted by NTNU. Below are some photos highlighting mainly the more informal part of the meeting. For Part 1, please see Radiocarbon Vol. 61(5), 2019.

On behalf of the Organizing Committee,

\section{Marie-Josée Nadeau}

Guest editor

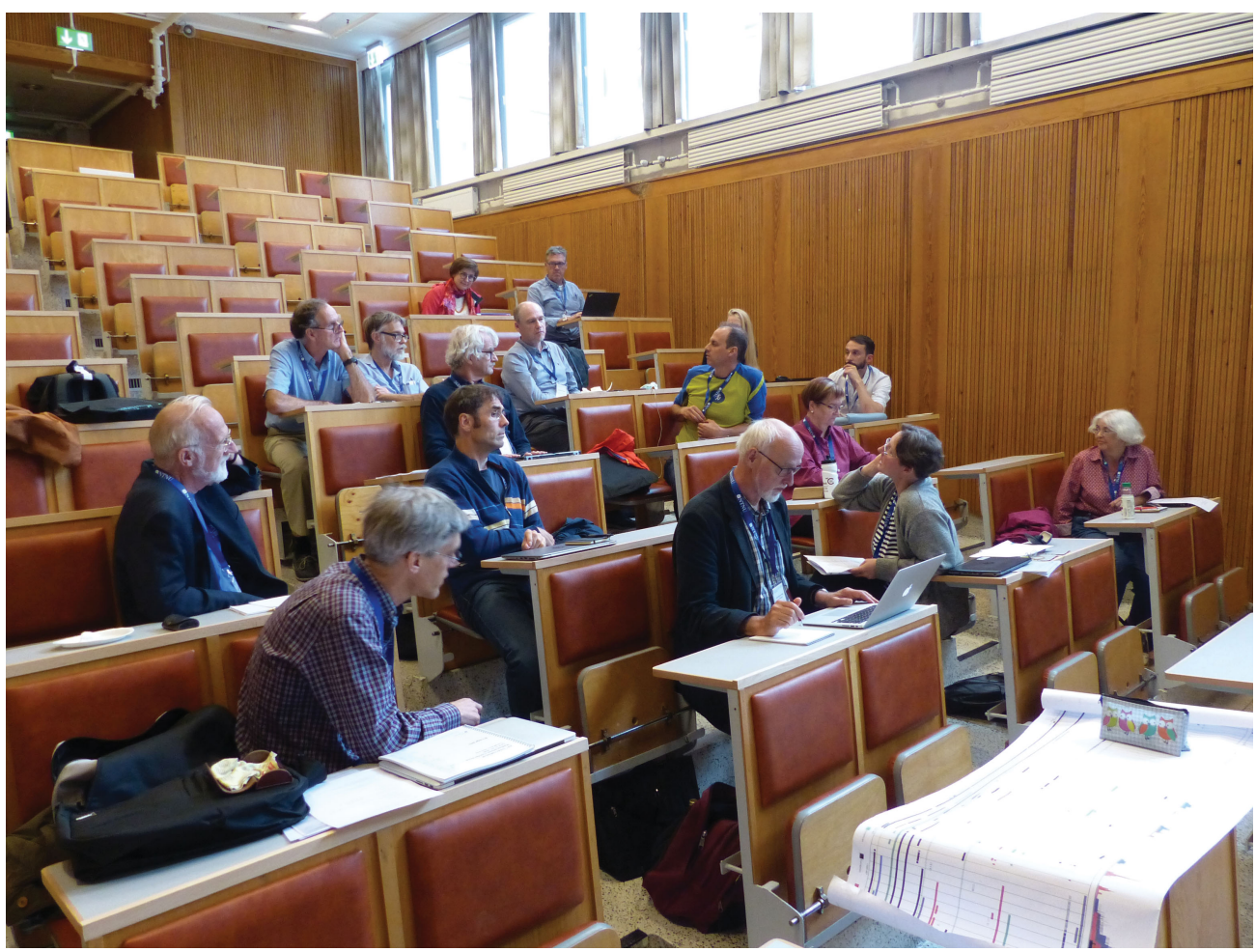

Discussion in the IntCal group meeting before the conference. 


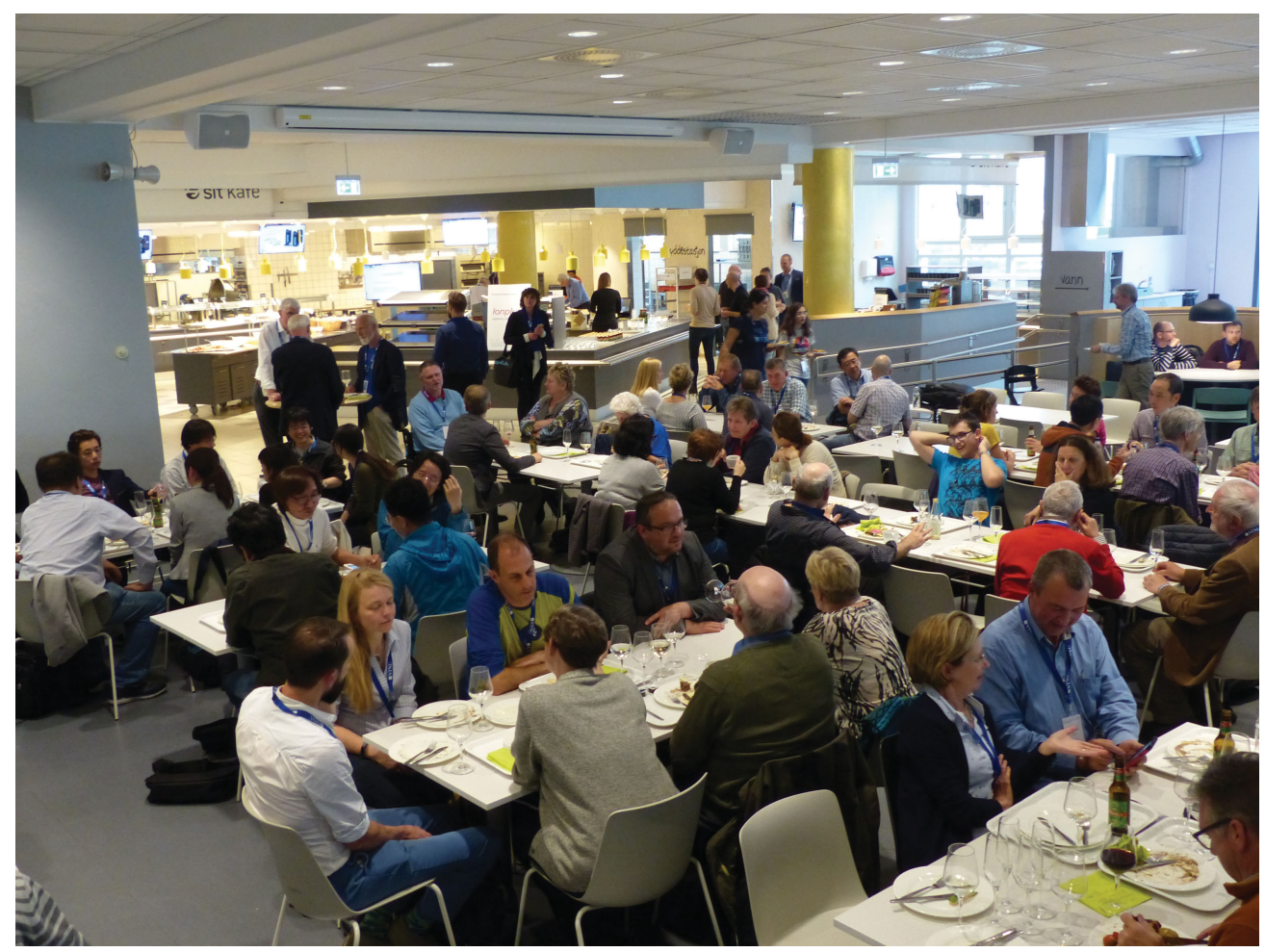

People meeting at the welcome reception on Sunday before the conference. 


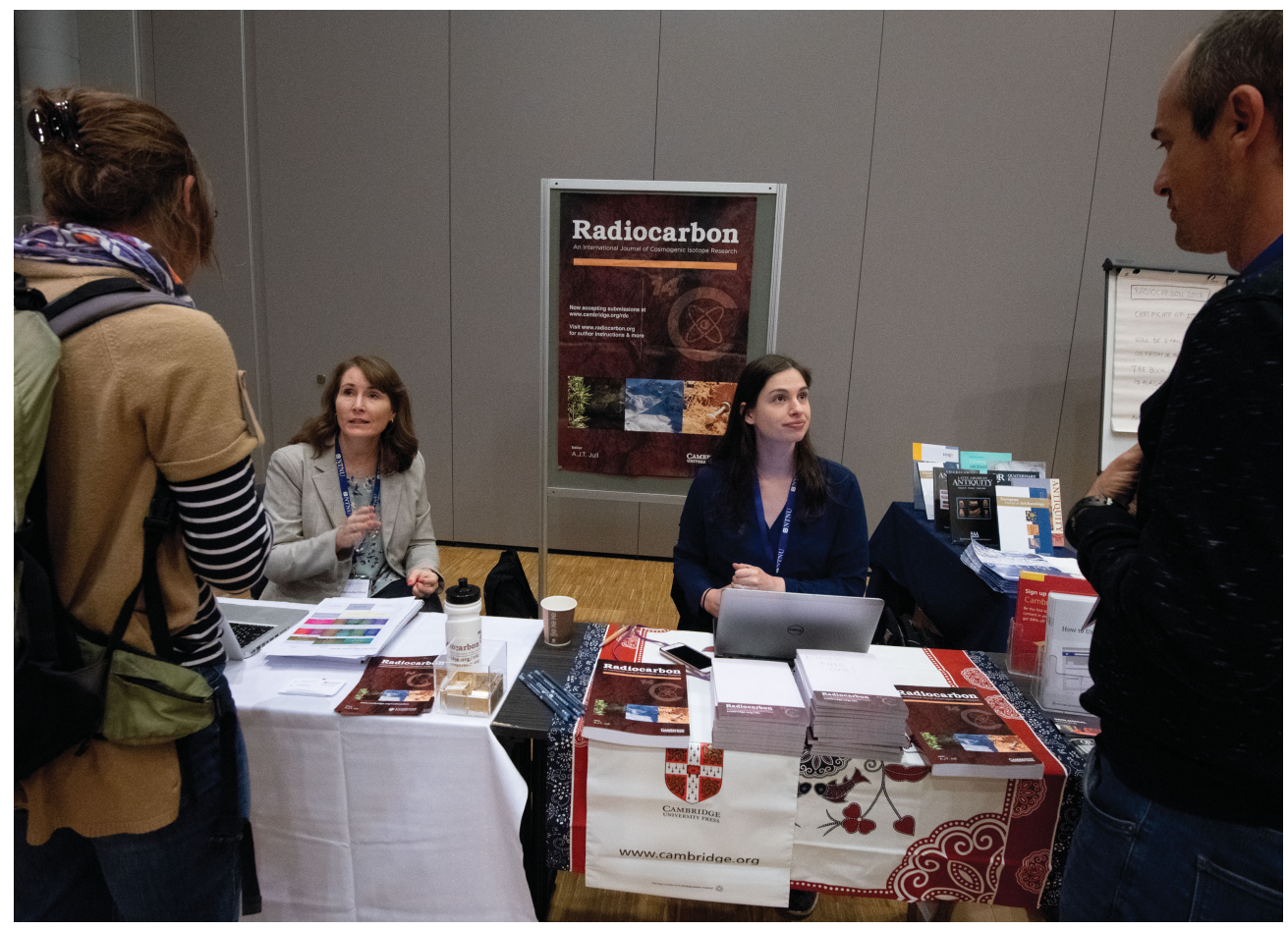

One of the exhibitor tables during the conference. We guess you know which exhibitor.

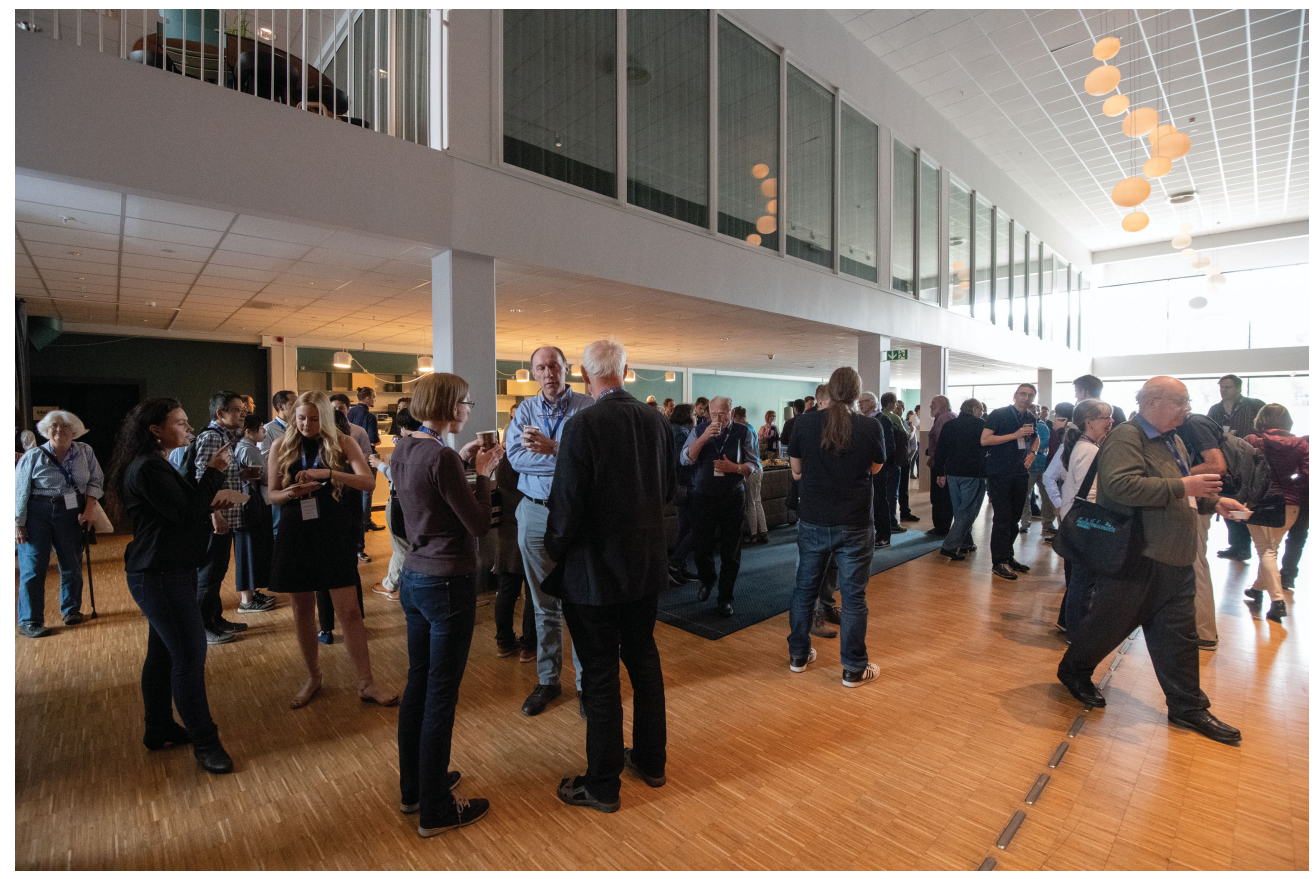

Conference attendees enjoying coffee and conversation during a coffee break. 
viii

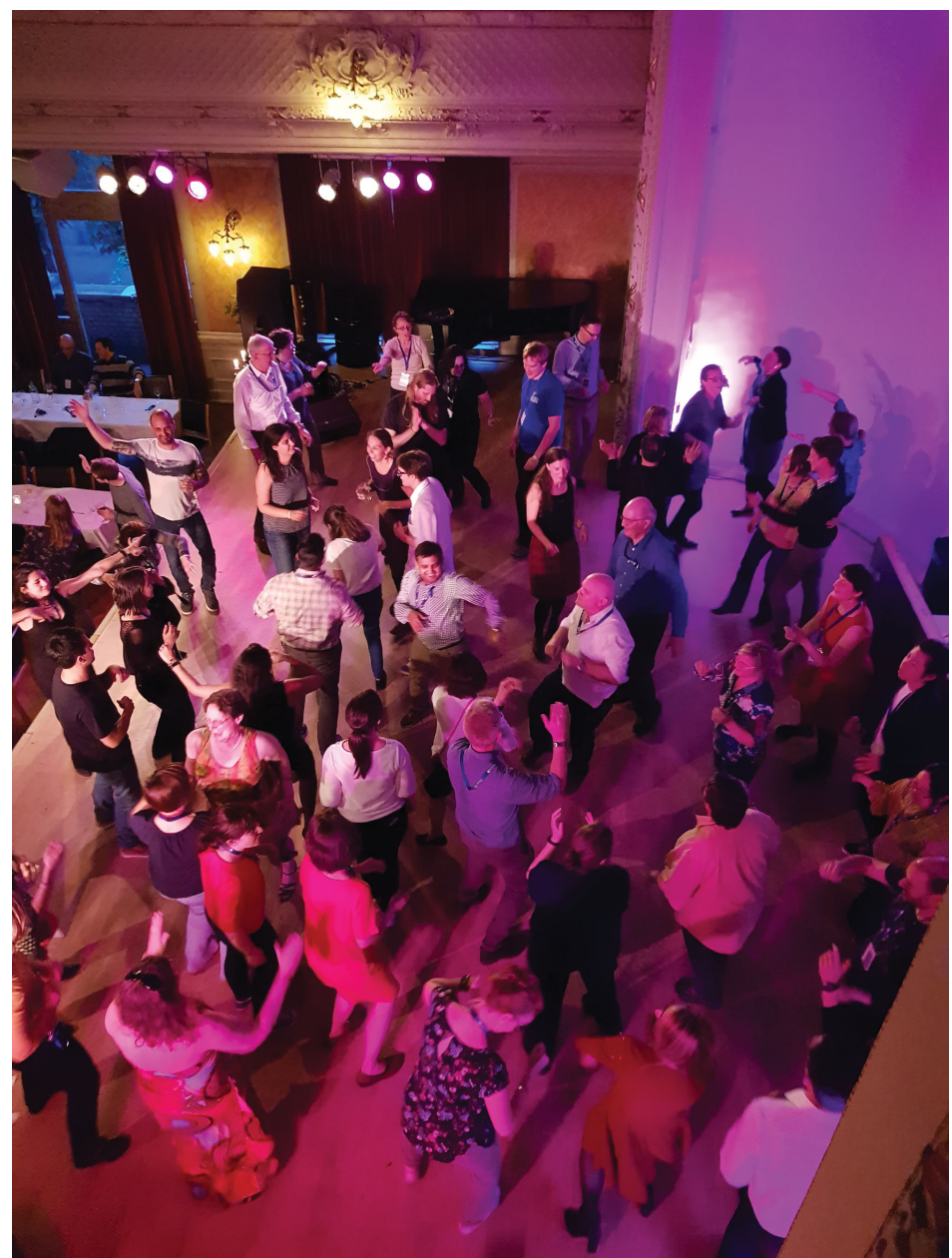

Dancing in the later stages of the conference dinner. 